\title{
鉄道台車のモーメントに着目した横圧推定式の検討
}

\section{A study of lateral-force estimation equation focusing on moment of a train bogie}

\author{
Takayuki TANAKA* ${ }^{* 1}$, Hisayo DOI ${ }^{* 1}$, Takefumi MIYAMOTO*1 ${ }^{* 1}$ and Hitoshi IIJIMA*2 \\ ${ }^{* 1}$ Railway Technical Research Institute \\ 2-8-28 Hikari-cho, Kokubunji-shi, Tokyo 185-8540, Japan \\ ${ }^{* 2}$ East Japan Railway Company \\ 2-479 Nisshin-cho, Kita-ku, Saitama-shi, Saitama 331-8513, Japan
}

\section{Received 22 February 2016}

\begin{abstract}
When railway vehicles pass through a sharp curve, yaw moment is generated at the bogie. This condition affects the increase of the lateral force of the outside wheel of the front axle of the leading bogie, which is important factor for assessing the running safety of railway vehicles. A Lateral-force/Wheel-load estimation equation has been developed as a method to calculate the lateral force and the wheel load during the curve passage of railway vehicles taking into account the yaw moment of the bogie. This equation is useful to estimate the risk of flange-climb derailment. The authors have newly suggested a more versatile Lateral-force/Wheel-load estimation equation with a focus on the improvement of the estimation of yaw moment of the bogie. Running tests using test track which has sharp curves were carried out to measure the generated forces of several components of the bogie, which are the sources of the yaw moment of the bogie. New equations were produced based on the test results, and compared with the measured lateral forces and wheel loads.
\end{abstract}

Key words : Railway, Railway vehicle, Vehicle dynamics, Running performance, Flange climbing

\section{1. はじめに}

車両・軌道条件，走行速度をパラメータとして，輪重や横圧の推定值を算出し，走行安全性を評価することの できる輪重横圧推定式がある（国土交通省鉄道局監修・土木関係技術基準調查研究会編，2002，2007）（内田 他，2001). 本式は急曲線をカント超過で $10 \mathrm{~km} / \mathrm{h}$ 程度の低速で走行する車両に適用可能であるが，カント不足 で走行する場合や高速で走行する場合における推定精度の検証はなされていない. このような場合にも輪重・横 圧を簡易に推定することのできる方法の確立が求められている．様々な車両，軌道，走行条件の組み合わせに対 して，精度のよい輪重・横圧推定を可能にするためには，現行式の計算方法の改良が必要である．本検討では， 特にカント不足状態で走行する場合に着目した現行式の改良方策について述べる.

改良方策として，本検討では，台車中心軸周りに働く台車旋回モーメント（ヨー回転モーメント）に起因する 横圧の推定に着目した．車両の進行方向に向かって先頭台車の前側軸（第 1 軸）で，曲線外軌側に位置する車輪 の横圧発生要因の一つに，第 1 軸に作用する横力（輪軸横圧）がある．定常的な輪軸横圧は，台車に働く台車旋 回モーメントのつり合い条件により算出できる．台車旋回モーメントが生じる要因には，曲線通過時に台車が車 体に対してボギ一角を持つ時に発生する空気ばねのねじれや，車輪・レール間で発生する左右方向・前後方向接

\footnotetext{
No.16-00054 [DOI:10.1299/transjsme.16-00054], J-STAGE Advance Publication date : 12 September, 2016

${ }^{* 1}$ 正員，（公財）鉄道総合技術研究所（厂185-8540 東京都国分寺市光町 2-8-38）

*2 正員，東日本旅客鉄道（株）（テ331-8513＼cjkstart埼玉県さいたま市北区日進町 2-479）

E-mail of corresponding author: tanaka.takayuki.98@rtri.or.jp
} 
線力，ヨーダンパ減衰力などが挙げられる．台車中心軸周りに㗢く台車旋回モーメントのつり合い条件を考える と, 急曲線では台車旋回モーメントは第 1 軸を外軌側に押し出す力として作用し, 結果として第 1 軸外軌側車輪 の横圧は増大寸る. したがって, 曲線通過時の台車旋回モーメントを推定することは, 乗り上がりに対する評価 の際に重要である．現行式では，台車旋回モーメントによる横圧増大分をカント超過状態での急曲線走行を仮定 した時刻歴シミュレーションにより得られるパラメータを用いて推定している. しかしながら，カント不足状態 での走行時にもこのパラメータによる推定横圧が精度よく実態を表しているかについて，検証はなされていなか った.

そこで，急曲線走行試験を鉄道総研所内試験線（RTRI 試験線）ならびに東日本旅客鉄道所有のカントの無い 構内線（JRE 試験線）にて実施し，その時の台車旋回モーメントのつり合い状態を実測した（田中他，2014）. 本論文では走行試験結果を報告すると共に，輪重横圧推定式の適用範囲を拡大するための一方策として検討し た，台車旋回モーメントに着目した推定横圧計算手法の改良策について述べる.

\section{2. 輪重横圧推定式}

\section{$2 \cdot 1$ 従来の輪重横圧推定式}

輪重横圧推定式は, 曲線通過時の輪重と横圧の発生メカニズムと実測データの解析結果より導かれる式であ り, 車両諸元と軌道条件, 走行条件を勘案し, 簡易な近似式によりカント超過状態での走行時における輪重や横 圧を計算できる，急曲線の低速走行時の乗り上がり脱線に対する安全性評価に直接的に関係する指標である, 進 行方向先頭台車の第1 軸の外軌側の横圧 $\mathrm{Q}_{0}$ は，輪重横圧推定式では式（1）のように記述される.

$$
\mathrm{Q}_{0}=\overline{\mathrm{Q}}_{1}+\Delta \mathrm{Q}_{\mathrm{AS}}+\Delta \mathrm{Q}_{\mathrm{AD}}+\Delta \mathrm{Q}_{\text {unsp }}
$$

$\overline{Q_{1}}$ は内軌側車輪の定常横圧であり, 内軌側横圧輪重比と内軌側輪重との積で算出される. $\Delta Q_{A S}$ は定常輪軸横 圧， $\Delta Q_{A D}$ は軌道不整に起因する外軌側横圧変動分， $\Delta Q_{\text {unsp }}$ はレール継ぎ目を通過の際に発生する外軌側横圧

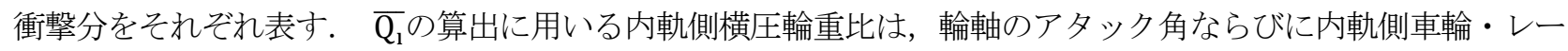
ル間の摩擦係数により変化する．車両が急曲線を通過する場合はアタック角が大きくなり，内軌側横圧輪重比は 内軌側車輪・レール間の動摩擦係数に漸近する。

式（1）において，台車旋回モーメントに関連する項は， $\Delta Q_{A S}$ で与えられる定常輪軸横圧項である. この項 は，第 1 軸における輪軸自体に作用する横力を表しており，式（2）のように書き下される.

$$
\begin{aligned}
\Delta \mathrm{Q}_{\mathrm{AS}} & =W_{0}\left(\frac{v^{2}}{g R}-\frac{C}{G}\right)+\mathrm{F}_{1} \\
& =W_{0}\left(\frac{v^{2}}{g R}-\frac{C}{G}\right)+\beta \times \frac{2 k b_{2}{ }^{2} c}{a R}
\end{aligned}
$$

ただし $W_{0}$ は第 1 軸の静止軸重, $v$ は走行速度, $G$ は軌間, $C$ カント, $R$ は曲線半径, $g$ は重力加速度, $2 b_{2}$ は枕 ばね間隔， $2 a$ は軸距， $2 c$ は台車間距離， $k$ は枕ばねの前後剛性， $\beta$ は補正係数である. 式 (2) 右辺の第 1 項は 遠心力とカントのつりあいを示し，第 2 項はねじれた枕ばねが戻ろうとする力による輪軸横圧 $\left(=\mathrm{F}_{1}\right)$ を示す.

また, 急曲線通過時に第 1 軸外軌側車輪がフランジ部でレールと接触している際には, 輪軸に作用する横圧が 輪重にも影響を及ぼす．輪重横圧推定式ではフランジ角 $60^{\circ}$ の車輪がフランジ直線部でレールと接触している と仮定し，式（3）により第1軸内外軌の輪重推定を行う.

$$
\begin{aligned}
& P_{\mathrm{o}}=\bar{P}_{o}-\overline{\Delta P}+\mathrm{F}_{1} \times \frac{\eta}{\tan 60^{\circ}} \\
& P_{i}=\bar{P}_{i}+\overline{\Delta P}-\mathrm{F}_{1} \times \frac{\eta}{\tan 60^{\circ}}
\end{aligned}
$$

ただし $P_{0}, P_{i}$ はそれぞれ第 1 軸外軌側, 内軌側の輪重である. $\bar{P}_{o}, \bar{P}_{i}$ はそれぞれ第 1 軸外軌側, 内軌側輪重の定 常成分で, 静止輪重に遠心力・カントによる輪重の増減を加味した項である. $\overline{\Delta P}$ は平面性変位による輪重変 
動, $\mathrm{F}_{1} \times \frac{\eta}{\tan 60^{\circ}}$ は輪軸横圧による輪重変動分を表す， $\eta$ は補正係数で, 横圧が輪重に与える影響について, 車両 運動シミュレーションの結果と実測が合致するように導入されたものである.

\section{$2 \cdot 2$ 台車旋回モーメントに着目した輪重横圧推定式の改良方策}

式（2）で用いられる $\mathrm{F}_{1}$ は，ねじれた枕ばねが戻ろうとする力による輪軸横圧の変化分に補正係数 $\beta$ を掛け合 わせることで求められる. 実際には台車旋回モーメントのつり合い条件を考える際，㸚じれた枕ばねが戻ろうと

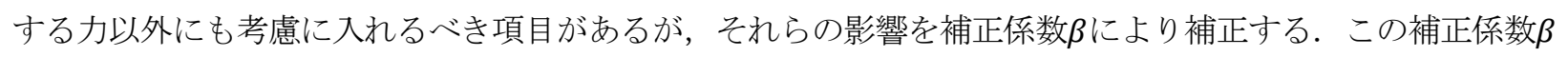

は, 本式で推定される輪軸横圧と, カント超過状態で走行する車両を仮定した際の車両運動シミュレーションに より求められる輪軸横圧を比較し, 両者が一致するように導入されたパラメータである. したがって, カント不 足状態で走行する際にも補正係数 $\beta$ を用いた推定横圧が精度良く実測值を推定しているかについては保障されて いない.

そこで，本論文ではモーメントの発生要因毎に，個々の発生力をカント条件によらず簡易的な式を用いて，補 正係数を用いずに推定する手法を検討した，それらの足し合わせにより，台車モーメントによる第 1 軸の輪軸横 圧変化量を推定することで, 適用範囲を拡大して使用可能な横圧推定手法を提案した.

曲線通過時の台車に働くモーメントの模式図を図 1 に示す. 曲線通過時の台車旋回モーメントのつりあい条件 より，第 1 軸の輪軸横圧を推定するためには，ねじれた枕ばねが戻ろうとする力の他に，第 1 軸と第 2 軸の車 輪・レール接触点で発生する前後方向接線力や第 2 軸の輪軸横圧の効果を考慮する必要がある. また, 台車にヨ ーダンパを装着した際には，その減衰力が台車旋回モーメントのつり合い状態に影響する. 今回の検討では, こ れらの力が台車モーメントのつり合い状態へ与える影響と, 対応する第 1 軸の輪軸横圧の変化量について定式化 した. また, 輪軸横圧が輪重に与える影響についても同様に, 式 (3) で用いられている補正係数 $を$ 用いずに 推定を行う手法を提案した。

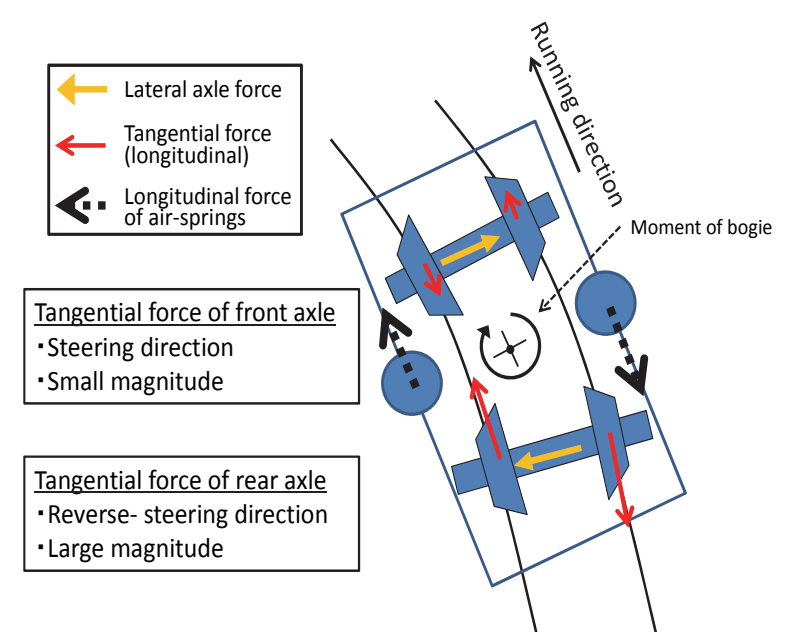

Fig. 1 Moment acting on the bogie during the curve passage

\section{3. 台車旋回モーメントのつり合い状態を考慮した輪重 ・横圧変化量の定式化}

\section{$3 \cdot 1$ 急曲線通過走行試験の概要}

台車旋回モーメントのつり合い状態の変化が第 1 軸の輪軸横圧に与える影響を実測により検証するため, RTRI 試験線において走行試験を実施した（田中他，2014）。走行試験に供した試験車両は在来線通勤型車両であ り, 新連続輪重横圧測定用（石田他，1997）の輪軸 2 対を先頭台車に装架した. 試験車両の様子を図 2 に示す. RTRI 試駼線は半径 $160 \mathrm{~m} （ \mathrm{R} 160 \mathrm{~m} ）$ および半径 100m （R100m）の曲線を有しており，それぞれのカントは $90 \mathrm{~mm}$ である. 試験線の線形を図 3 に示す. 試験車両の第 1 軸では, 第 1 軸外軌側の輪重が内軌側車輪に比べて 小さくなるように静止輪重のアンバランスを $0 〜 40 \%$ の範囲で設定した．また，曲線通過時の走行速度は 10〜 
$30 \mathrm{~km} / \mathrm{h}$ と設定した. 本走行試験では, 台車旋回モーメントの発生要因である, 先頭台車の全 4 輪の輪重・横 圧・前後方向接線力と, 先頭台車の左右の空気ばねから発生する力を実測した．また，ヨーダンパを装着した条 件での走行も実施し，その際にはヨーダンパ作用力も実測した。

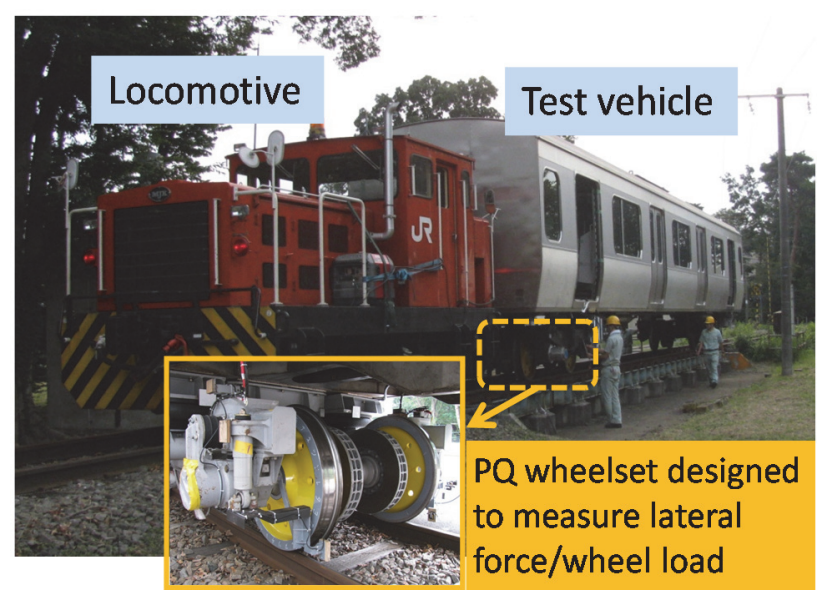

Fig. 2 Setup of test vehicle

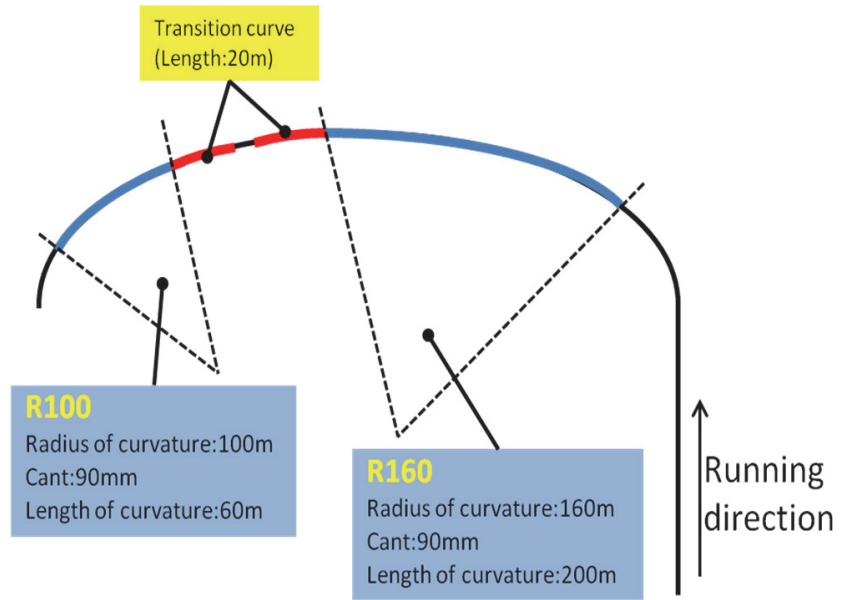

Fig. 3 Design of the RTRI testing track

\section{$3 \cdot 2$ 走行試験結果と定式化}

走行試験の結果を勘案して, 台車旋回モーメントの各発生要因から生じるモーメントを個々に推定する式を提 案した.さらに, これらのモーメントによる先頭台車第 1 軸輪軸横圧の変化量を, 台車内のモーメントのつり合 い式を第 1 軸輪軸横圧について解くことで導いた．本章で検討する提案式で用いる，特に説明がされていない物 理量については，車両の諸元値，軌道検測の実測値，ならびに文献（国土交通省鉄道局監修・土木関係技術基準 調査研究会編，2002）ならびに（内田他，2001）の手法による推定值を用いて計算を行った.

\section{$3 \cdot 2 \cdot 1$ 前後方向接線力}

先頭台車の車輪・レール間の前後方向接線力測定結果の一例を図 4 に示す. 図 4 において, 車両進行方向に作 用する力の向きを正方向とした.

円曲線の定常部では第 1 軸の前後方向接線力は外軌側で正方向, 内軌側で負方向に発生することから曲線に沿 って輪軸が操舵される方向（順操舵方向）にモーメントが働くことがわかる. 第 2 軸では, 外軌側で負方向, 内 軌側で正方向に前後方向接線力によるモーメントが発生することから, 第 1 軸とは逆に, 輪軸に働くモーメント は逆操舵方向となる. また, 図 4 よりわかるように, 前後方向接線力の絶対值は曲線内において第 1 軸より第 2 軸の方が大きい。したがって，第 1 軸と第 2 軸の前後方向接線力による合成モーメントは，第 1 軸を外軌側に押 しつける方向に作用するので, 結果として第 1 軸外軌車輪の横圧が増加する. この第 1 軸, 第 2 軸で発生する前 後方向接線力によるモーメントの方向や大きさの傾向は速度や静止輪重のアンバランスの条件によらず, 常に同 じであった。

急曲線走行時の前後方向接線力は車輪・レール間のクリープ力により生じる. そこで, 走行試験結果を鑑みな がら, 前後方向接線力, 寸なわち前後クリープカをクリープ理論に基づいて定式化した. 以下, 各車輪におい て, $\mathrm{m}$ を軸を表す添字 ( $\mathrm{m}=1$ :第 1 軸, $\mathrm{m}=2$ : 第 2 軸 $), \mathrm{n}$ を内外軌を表す添字 $(\mathrm{n}=$ out :外軌, $\mathrm{n}=$ in :内軌）と定義 する.

走行試験結果から，急曲線走行時にはすべりが大きく，前後・左右のクリープ力はほぼ摩擦力に飽和している と考えられるため, 本検討では, まず左右クリープ力を導出し, 摩擦力から差し引くことで前後クリープ力を導 出する手法を用いる. 車輪・レール接触点における左右方向の等価摩擦係数 $\mu_{\mathrm{emn}}$ はレビ・シャルテの式に基づ き，式(4)で表わされる. 


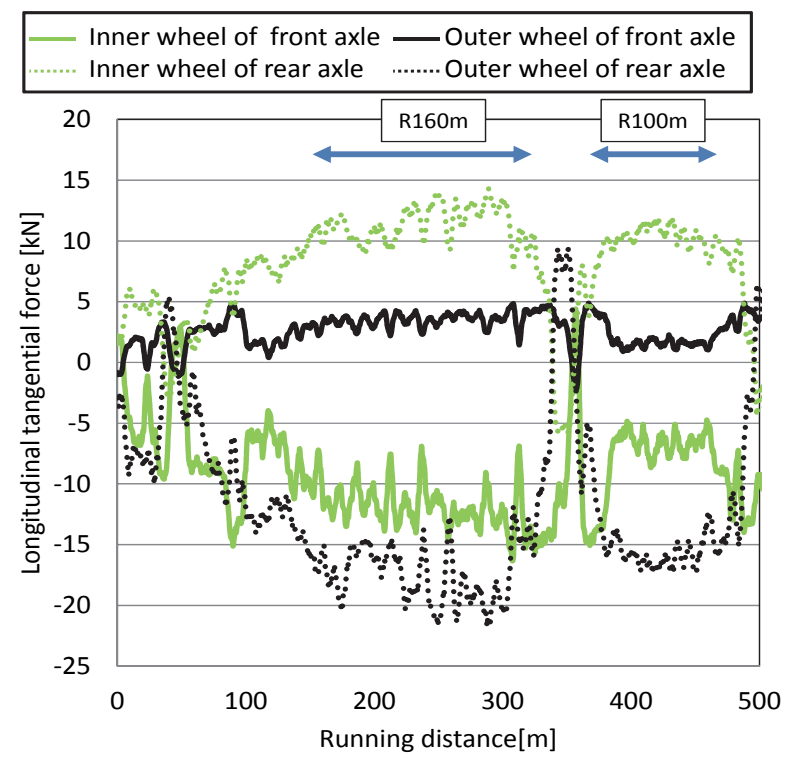

Fig. 4 Longitudinal tangential force

$$
\mu_{\mathrm{emn}}=\mu \times \frac{\frac{\kappa_{\mathrm{mn}} v_{\mathrm{ymn}}}{\mathrm{N}_{\mathrm{mn}}}}{\left(\mu^{\tilde{\beta}}+\left(\frac{\mathrm{k}_{\mathrm{mn}} v_{\mathrm{ymn}}}{\mathrm{N}_{\mathrm{mn}}}\right)^{\tilde{\beta}}\right)^{\frac{1}{\tilde{\beta}}}}
$$

ただし， $\mu$ は車輪・レール間の摩擦係数， $\mathrm{N}_{\mathrm{mn}}$ は車輪・レール接触点における法線力， $\kappa_{\mathrm{mn}}$ は左右クリープ係数， $v_{\mathrm{ymn}}$ は左右クリープ率， $\tilde{\beta}$ はクリープ力の飽和特性を表わ寸指数であり，ここでは $\tilde{\beta}=1.5$ とした．また，左右ク リープ係数と法線力の比 $\kappa_{\mathrm{mn}} / \mathrm{N}_{\mathrm{mn}}$ は式（5）のように表わされる（脱線に対する安全基準研究グループ，1968）。

$$
\begin{aligned}
& \frac{\kappa_{\mathrm{mn}}}{\mathrm{N}_{\mathrm{mn}}}=\mathrm{H}_{\mathrm{mn}} \sqrt[3]{\frac{9 \mathrm{E}\left(1+v^{2}\right)^{2}}{\mathrm{~N}_{\mathrm{mn}} \mathrm{R}_{\mathrm{cmn}}{ }^{2}}} \\
& \mathrm{R}_{\mathrm{cmn}}=\frac{1}{\mathrm{R}_{\mathrm{wxmn}}}+\frac{1}{\mathrm{R}_{\mathrm{wymn}}}+\frac{1}{\mathrm{R}_{\mathrm{rxmn}}}+\frac{1}{\mathrm{R}_{\mathrm{rymn}}}
\end{aligned}
$$

ただし, Eは鉄（車輪・レールの構成材料）の縦弾性係数, vは鉄のポアソン比， $\mathrm{H}_{\mathrm{mn}}$ は 2 つのヘルツの接触楕円 定数の積, $\mathrm{R}_{\mathrm{wxmn}}, \mathrm{R}_{\mathrm{wymn}}, \mathrm{R}_{\mathrm{rxmn}}, \mathrm{R}_{\mathrm{rymn}}$ はそれぞれ接触点における, 車輪前後方向, 車輪左右方向, レール前 後方向, レール左右方向の曲率半径である. 左右クリープ率 $v_{\mathrm{ymn}}$ は式（6）のように置く.

$$
v_{\mathrm{ymn}}=\frac{\psi_{\mathrm{Wm}}}{\cos \alpha_{\mathrm{mn}}}
$$

ただし， $\alpha$ は車輪・レール間の接触角， $\psi_{\mathrm{Wm}}$ は輪軸のアタック角である. 車輪・レール接触点における法線力 $\mathrm{N}_{\mathrm{mn}}$ は，式（7）のように書ける.

$$
\mathrm{N}_{\mathrm{mn}}=\mathrm{P}_{\mathrm{mn}} \cos \alpha_{\mathrm{mn}}\left(1+\frac{\mathrm{Q}_{\mathrm{mn}}}{\mathrm{P}_{\mathrm{mn}}} \tan \alpha_{\mathrm{mn}}\right)
$$

ここで，第 1 軸外軌側の前後方向接線力について検討する. 本検討での対象が急曲線走行時であることから， 第 1 軸外軌側ではフランジ接触状態で走行していると仮定できる. このとき, 式 (5) において $\mathrm{R}_{\mathrm{wx} 1 \mathrm{out}}=$ $\mathrm{R}_{\mathrm{wyl} \text { out }}=\mathrm{R}_{\mathrm{rxlout}}=\infty$ であり， $\mathrm{R}_{\mathrm{ry} 1 \text { out }}$ はレール肩部の曲率半径に等しいと見なすことができる．式（6)，（7）で は接触角 $\alpha_{1 \text { out }}$ をフランジ角とした. Nadal の式により与えられる, 乗り上がり開始時の $\frac{\mathrm{Q}_{\mathrm{mn}}}{\mathrm{P}_{\mathrm{mn}}}$ 值はフランジ・レ 
一ル間の摩擦係数によって変化し，概ね $0.94 \sim 1.14$ となる. 今回の検討にて取り扱う急曲線部では, 第 1 軸外軌 側は，ほぼ乗り上がり開始状態にあると仮定し，代表值として式（7）の右辺において， $\frac{\mathrm{Q}_{\mathrm{mn}}}{\mathrm{P}_{\mathrm{m}}} \fallingdotseq 1$ とおいた。これ により，計算を簡略化し，法線力 $\mathrm{N}_{1 \text { out }}$ を輪重 $\mathrm{P}_{1 \text { out }}$ の関数として表現することができる．なお， RTRI 試験線での 走行試験結果では, 半径 $160 \mathrm{~m}$ ，ならびに半径 $100 \mathrm{~m}$ の急曲線を通過する際に, $\frac{\mathrm{Q}_{\mathrm{mn}}}{\mathrm{P}_{\mathrm{mn}}}$ 実測値は $0.6 〜 1.4$ 程度にば らつく．しかしながら，式（7）で $\frac{\mathrm{Q} \mathrm{mn}}{\mathrm{P}_{\mathrm{mn}}}$ の仮定值を実測值のばらつき分程度変化させても, 結果として推定横圧が 受ける影響は小さいことを確認した。 さらに，車輪・レール間のすべり率が著大であり，前後と左右のクリープ 力の合力は摩擦力 $\mu N_{1 \text { out }}$ に飽和していると仮定し, ここから左右クリープカ $\mu_{\mathrm{e} 1 \text { out }} N_{1 \text { out }}$ の成分を減じると, 第 1 軸外軌側での前後クリープ力は式（8）のように算出できる.

$$
T_{1 \text { out }}=\sqrt{\left(\mu N_{1 \text { out }}\right)^{2}-\left(\mu_{\mathrm{e} 1 \text { out }} N_{1 \text { out }}\right)^{2}}
$$

ただし，式(8)で用いる $\mu_{\mathrm{e} \text { lout }}, N_{\text {lout }}$ は，仮定条件を式 (4) 〜 (7) にあてはめて導く.

次に, 第 1 軸内軌側について検討する. 第 1 軸内軌側の前後クリープカは, 第 1 軸外軌側の前後クリープカと 相関が高く, 解析的に求める解よりも, 第 1 軸外軌側の前後クリープ力の関数として表わす方が試験結果をよく 表現できることが分かった，そこで，第 1 軸内軌側の車輪はレールと踏面接触しており $\left(\alpha_{1 \text { in }} \fallingdotseq 0\right)$, 前後クリー プ率が第 1 軸外軌側と等しいと仮定し，微小な項を無視すると，第 1 軸内軌側の前後クリープカは，式（9）の ように表わせる。

$$
T_{1 \text { in }}=-T_{1 \text { out }}\left(\frac{N_{1 \text { in }}}{N_{1 \text { out }}}\right)^{\frac{2}{3}}
$$

次に，第 2 軸について検討する. 走行試験結果を鑑みて，第 2 軸の各車輪は踏面接触しており $\left(\alpha_{2 n} \fallingdotseq 0\right)$, 第 1 軸外軌側と同様, 前後と左右のクリープ力の合力は摩擦力 $\mu N_{2 n}$ に概齐飽和していると仮定する.

走行試験では, 曲線通過時の第 1 軸のアタック角 $\psi_{\mathrm{W} 1}$ と第 2 軸のアタック角 $\psi_{\mathrm{W} 2}$ との間の相関を調査した. そ の結果，図５に示寸ような相関が得られた。この関係は近似的に式（10）のように表わすことができる.

$$
\psi_{\mathrm{W} 2}=\frac{\pi \sqrt{\psi_{\mathrm{W} 1}}}{376}
$$

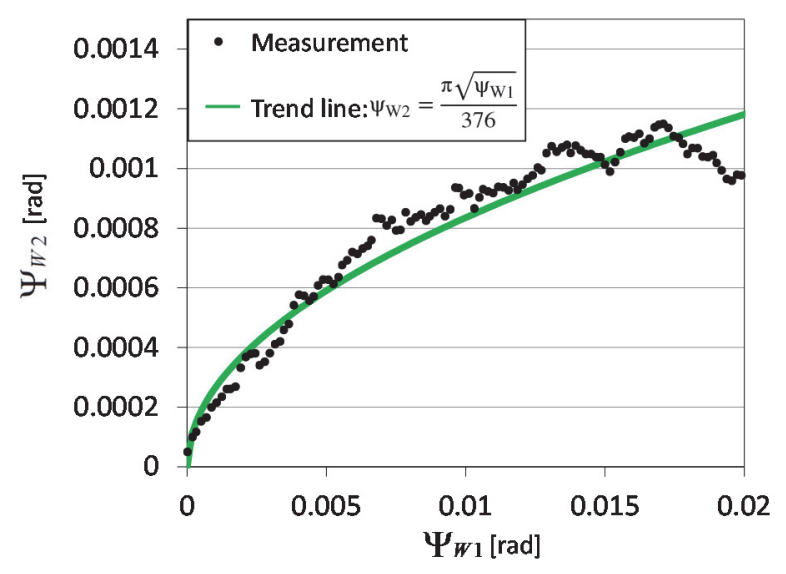

Fig. 5 Correlation between attack angle of No.1 and No.2 axle

以上より, 第 2 軸内外軌の前後クリープ力は式（11）のように算出できる. 
(外軌)

$$
T_{2 o u t}=-\sqrt{\chi^{2}\left(\mu N_{2 o u t}\right)^{2}-\left(\mu_{\mathrm{e} 2 \text { out }} N_{2 \text { out }}\right)^{2}}
$$

(内軌)

$$
T_{2 i n}=\sqrt{\chi^{2}\left(\mu N_{2 \text { in }}\right)^{2}-\left(\mu_{\mathrm{e} 2 \text { in }} N_{2 i n}\right)^{2}}
$$

ただし, $\chi$ は飽和率である. また, $\mu_{\mathrm{e} 2 \mathrm{in}}, N_{2 i n}, \mu_{\mathrm{e} 2 \text { out }}, N_{2 \text { out }}$ の各数值は, 仮定条件ならびに式 (10) を式

（4）〜（7）にあてはめて算出する. 飽和率 $\chi$ は前後・左右クリープの合力とクーロン摩擦力 $\mu N_{2 \mathrm{n}}$ との比として 定義され, 前後・左右クリープ力の合力がクーロン摩擦力に飽和した時を $\chi=1$ とする. ある走行地点での $\chi$ は実 測値を用いて，第2軸の内外軌の平均値として，式(12)のように表わす.

$$
\chi=\frac{1}{2}\left(\frac{\sqrt{\widetilde{T}_{\text {2out }}{ }^{2}+\widetilde{Q}_{\text {2out }}{ }^{2}}}{\mu \widetilde{P}_{\text {out }}}+\frac{\sqrt{\widetilde{T}_{2 \text { in }}{ }^{2}+\widetilde{Q}_{2 \text { in }}{ }^{2}}}{\mu \widetilde{P}_{2 \text { in }}}\right)
$$

ただし， $\widetilde{T}_{m n}$ は前後方向接線力の測定值， $\tilde{Q}_{m n}$ は横圧の測定值， $\tilde{P}_{m n}$ は輪重の測定值である. 一例として RTRI 試験線の走行試験結果より得られる，RTRI 試験線内の 2 つの円曲線（R160m，R100m）の実測した曲線半

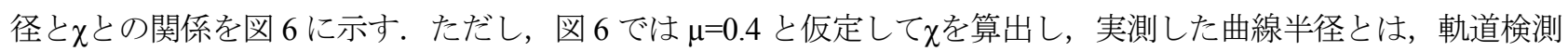
の結果から得られる正矢量（須田他，1997）より算出した值である. 今回検証を行う R160m, R100m の区間で はメの值は 1 周りに分布していることを確認した. したがって, 本論文では, 当該区間では一律 $\chi=1$ とおいて第 2 軸の前後方向接線力の算出を行った.

以上より, 先頭台車内における各車輪・レール間の前後方向接線力によるモーメント $\Delta M_{T F}$ と, これによる第 1 軸輪軸横圧の変化分 $\Delta Q_{T F}$ は次式のように表わされる.

$$
\Delta Q_{T F}=\frac{\Delta M_{T F}}{a}=\frac{b}{a} \sum_{m, n} T_{m n}
$$

式（13）により算出した $\Delta Q_{T F}$ と実測とを比較したものを図 7 に示す. R160m の区間は R $100 \mathrm{~m}$ の区間と比べる

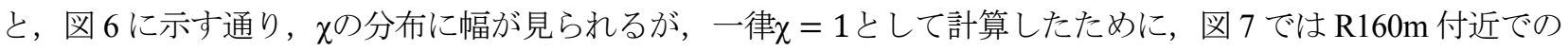
実測と推定值で細かい変動の様子が異なる. 今後, 様々な曲線の走行データを集積し, 曲線半径に対する飽和率 の傾向を把握する必要がある.

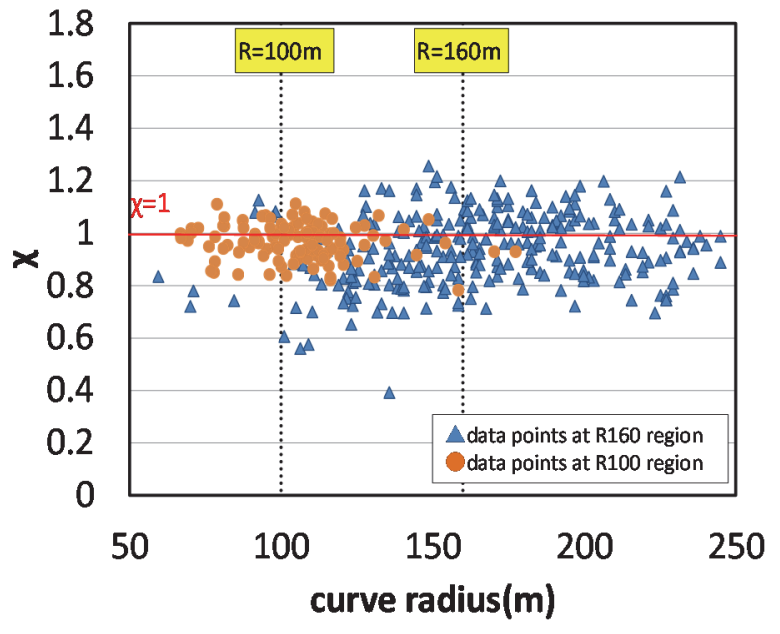

Fig. 6 Correlation between curve radius and saturation factor $\chi$ from the measurement

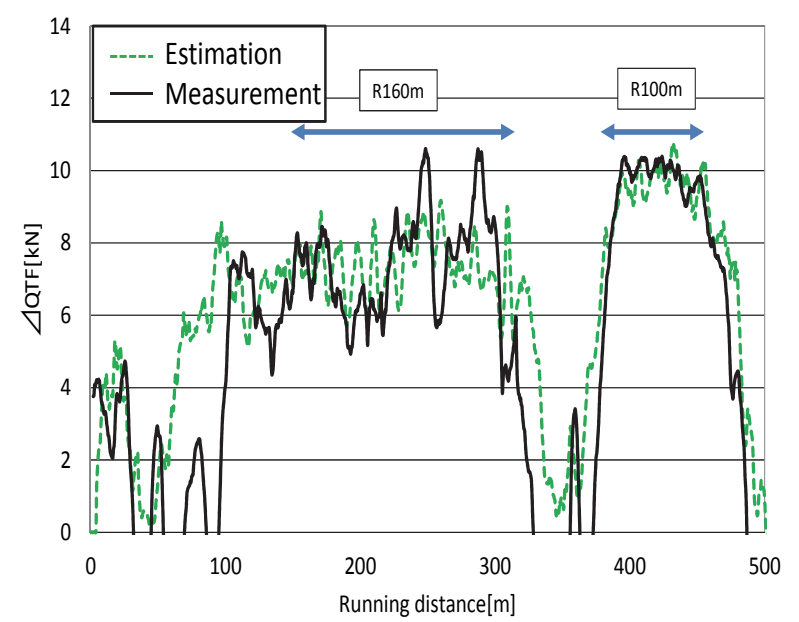

Fig. 7 Variation of lateral force of front axle due to the longitudinal tangential force $\left(\Delta Q_{T F}\right)$ 


\section{$3 \cdot 2 \cdot 2$ 第 2 軸の輪軸横圧}

台車内のモーメントのつりあいを考えると，超過遠心力の影響は第 1 軸，第 2 軸で相殺されるので，第 2 軸の 輪軸横圧により台車に作用するモーメント $\Delta M_{A 2}$ は左右クリープカ $\mu_{\mathrm{e} 2 \mathrm{n}} N_{2 \mathrm{n}}$ により発生すると考えられる. したが つて第 2 軸の輪軸横圧による第 1 軸輪軸横圧の変化分 $\Delta Q_{A 2}$ は第 2 軸内外軌の左右クリープ力の足し合わせによ り，式（14）のように与えられる.

$$
\Delta Q_{A 2}=\frac{\Delta M_{A 2}}{a}=-\frac{a\left(\mu_{\mathrm{e} 2 o u t} N_{2 o u t}+\mu_{\mathrm{e} 2 \text { in }} N_{2 \text { in }}\right)}{a}
$$

ここで 2 aは軸間距離である。従来から台車内で後位軸に当たる第 2 軸はアタック角が小さいと考えられてお り, 図 5 で示すように実測でもこのことを確認した。 ただし，式(6)に示すように，アタック角の微小な変化に 対して左右クリープ率も変化する. この変化により， $\mu_{\mathrm{e} 2 o u t}, \mu_{\mathrm{e} 2 \text { in }}$ は大きく影響を受けるため, 結果として $\Delta Q_{A 2}$ も変化する. 走行試験では第 2 軸のアタック角は円曲線内において $\pm 0.02 \mathrm{deg}$ 程度のばらつきがあつた．本 検討ではこのばらつきによる増減を含んだ推定值として $\Delta Q_{A 2}$ を見積もることとする. 図 8 に $\Delta Q_{A 2}$ の推定值と実 測值を比較したものを示す. 図 8 に示す通り， $\Delta Q_{A 2}$ は幅を持った推定領域として表わされるが，曲線部におい ては実測值が概ね推定領域内にあることを確認した。

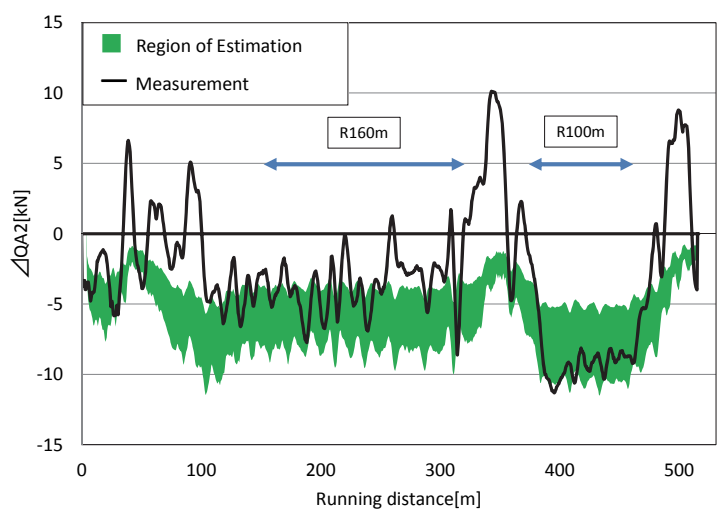

Fig. 8 Variation of lateral force of front axle due to the lateral force of rear axle $\left(\Delta Q_{A 2}\right)$

\section{$3 \cdot 2 \cdot 3$ 枕ばね}

従来の横圧推定式で用いられている手法では空気ばねのねじれにより台車に作用するモーメント $\Delta M_{\widetilde{A S}}{ }^{\prime}$ は台車 ヨー角に対して線形であると仮定しており式（15）のように与えられていた.

$$
\Delta M_{\overparen{A S}}{ }^{\prime}=2 k b_{2}^{2} \psi_{T}=\frac{2 k b_{2}^{2} c}{R}
$$

ここで， $\psi_{T}$ は台車ヨ一角である.

走行試験で空気ばねから発生する力を測定した。図 9 に示すように空気ばね下に 3 成分フォースセンサを挿入 することで, 先頭台車の 2 個の空気ばねから発生する力を測定し，この力が台車に与えるモーメントを調べた.
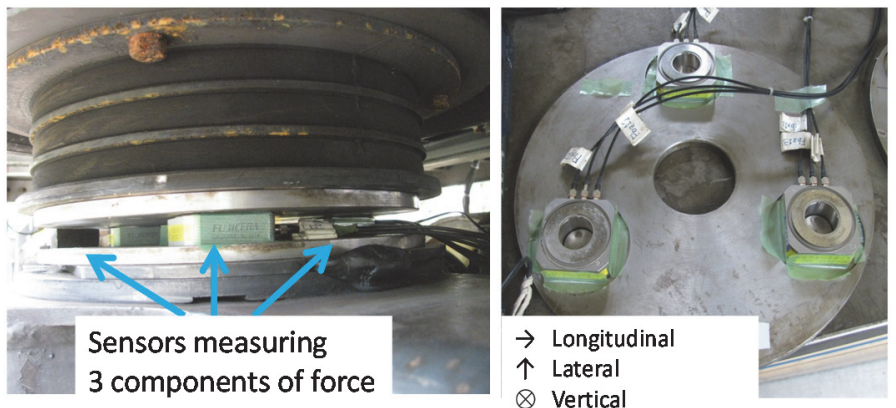

Fig.9 Measurement of air-spring force using force sensors 


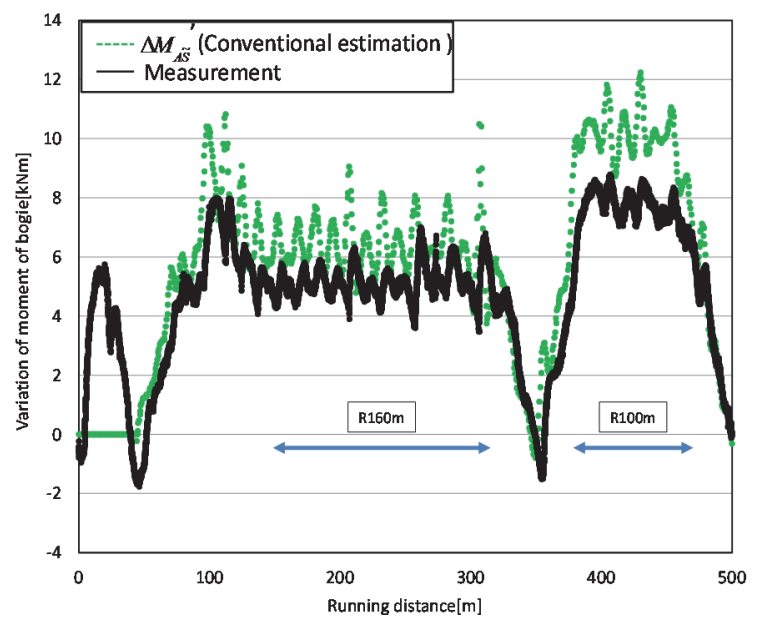

Fig. 10 Variation of moment of bogie affected by twist of air-spring

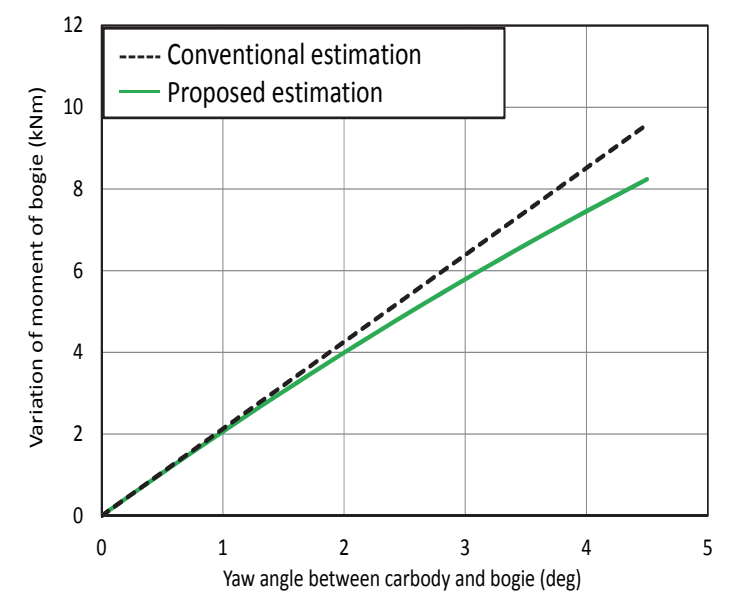

Fig. 11 Comparison of conventional and proposed estimation of moment of bogie affected by twist of air-spring

測定結果と, 従来の推定式の手法により算出される值を比較したものを図 10 に示す. 図 10 に示すように, 曲線 半径が小さい所，すなわち車体と台車間の相対ヨー角（台車ヨー角）が大きくなる所ほど, $\Delta M_{\overparen{A S}}{ }^{\prime}$ の推定結果が 実測值よりも大きくなっており，急曲線での走行を扱う際には従来の推定手法では大きめに見積もっていること が分かる．台車ヨ一角が大きくなると空気ばねの㸚じれによるモーメントが小さくなる傾向があることや，ヒス テリシスの存在により非線形な特性が見られることが，鉄道総研所有の台車旋回性能試験装置を用いた定置試験 において確認されている（田中他，2013）。走行試験で得られた台車ヨー角に対する空気ばねのねじれによるモ ーメントは，同種の空気ばねについて台車旋回性能試験装置で実施した試験結果と同等であったそそこで，定置 試験の結果に基づいて, 提案手法で用いる台車ヨー角に対する空気ばねのねじれによるモーメント $\Delta M_{\overparen{A S}} を$

（16）のように 2 次関数でモデル化する.

$$
\Delta M_{\widetilde{A S}}=-218 \psi_{T}^{2}+122 \psi_{T}
$$

ただし，ここではヒステリシスの影響は微小であり，無視する. また， $\psi_{T}$ に乗じる係数は今回の走行試験で用 いた空気ばねに対する同定值である，枕ばねが台車に与えるモーメントについて，式（16）で与えられるもの と, 従来式で用いられる, 台車ヨ一角に比例するものとの比較を図 11 に示す. 提案モデルでは概㸚台車ヨ一角 が $2 \mathrm{deg}$ を超えると従来モデルに比べ枕ばねが台車に与えるモーメントが顕著に小さくなることが分かる．在来 線車両では概ね, 半径 $200 \mathrm{~m}$ の曲線を通過する際に台車ヨー角が $2 \mathrm{deg}$ となるため, これより急な曲線を通過す る際にこの提案モデルを用いることで, 高精度な推定が可能になると考えられる. 式（16）を用いて計算を行う 際には, 台車ヨー角は台車中心間距離 $(2 c)$ と曲線半径 $R$ 用いて表される, $\psi_{T}=c / R$ という関係より導く. ここでは, 軌道変位の影響を含まない設計曲線半径を $R$ として用いる. 以上より空気ばねのねじれによる第 1 軸 輪軸横圧変化分は, 式（17）のように表わされる.

$$
\Delta Q_{\widetilde{A S}}=\frac{\Delta M_{\widetilde{A S}}}{a}
$$

\section{$3 \cdot 2 \cdot 4 \quad \exists$ ダンパ}

ヨーダンパが台車旋回モーメントに及ぼす動的な影響について調べるために，ヨーダンパ単体の性能試験によ り減衰特性を詳細に調査した上で, 台車左右に 1 本ずつヨーダンパを装架して走行試験を行った. 各ヨーダンパ の発生力およびそれらから算出される台車旋回中心軸周りのモーメントを図 12 に示す。これより, 緩和曲線の ように台車ヨ一角が一定方向に連続的に変化する所では, ヨ一角の変化率に比例する減衰力に起因するモーメン トが発生していることがわかる. 特に入口緩和曲線では, 輪軸横圧を定常的に増大させるため, 外軌側横圧が増 大寸る．また，台車内のモーメントのつりあい条件から，ヨーダンパによるモーメントは第 1 軸と第 2 軸の輪軸 
横圧をそれぞれ変化させる可能性が考えられたが，輪軸横圧の実測結果とヨーダンパ発生力の大きさを勘案する と, 急曲線走行時にはヨーダンパ発生力はほぼ第 1 軸の輪軸横圧にのみ影響を現れていることを確認した. 以上 より，ヨーダンパにより発生する第 1 軸輪軸横圧の増分 $\Delta Q_{Y D}$ を式（18）のように表す.

$$
\Delta Q_{Y D}=n_{d} \times \frac{\gamma d^{2} \tan \omega_{\mu T}}{a}
$$

ただし, $n_{d}$ は対象台車の装着ヨーダンパ本数, $\gamma$ はヨーダンパの減衰係数 $2 d$ はヨーダンパ取り付け間隔, $\omega_{\psi T}$ は台車ヨー角速度である．式（18）で与えられるヨーダンパによる輪軸横圧の増分を考慮した推定輪軸横圧と実 測值との比較を図 13 に示寸. 図 13 には, ヨーダンパを考慮しない従来の横圧推定式による計算值も合わせて示 す. $\Delta Q_{Y D}$ を考慮することにより，ヨーダンパの影響が顕著になる緩和曲線部において精度良く横圧を推定でき ることが確認できる.

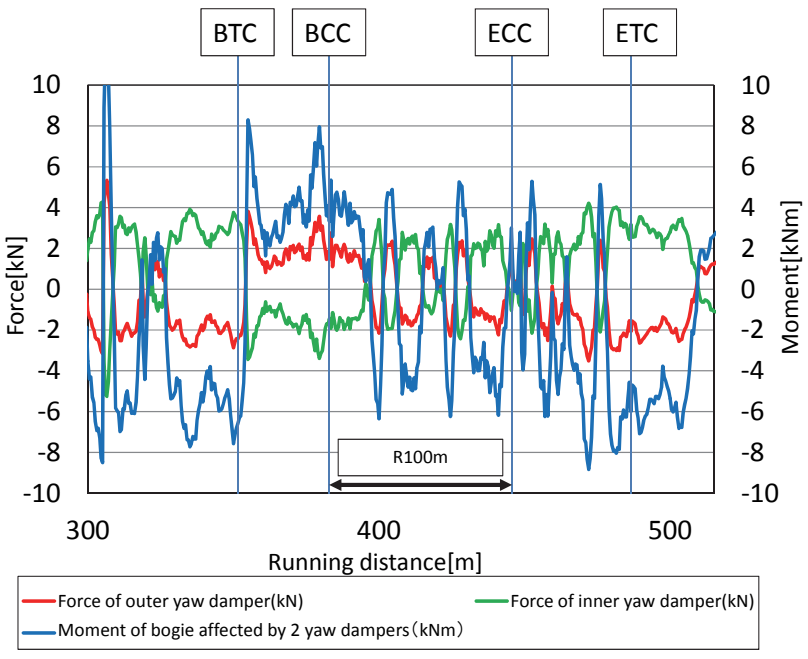

Fig. 12 Force of yaw dampers(left axis) and moment of bogie affected by yaw dampers(right axis)

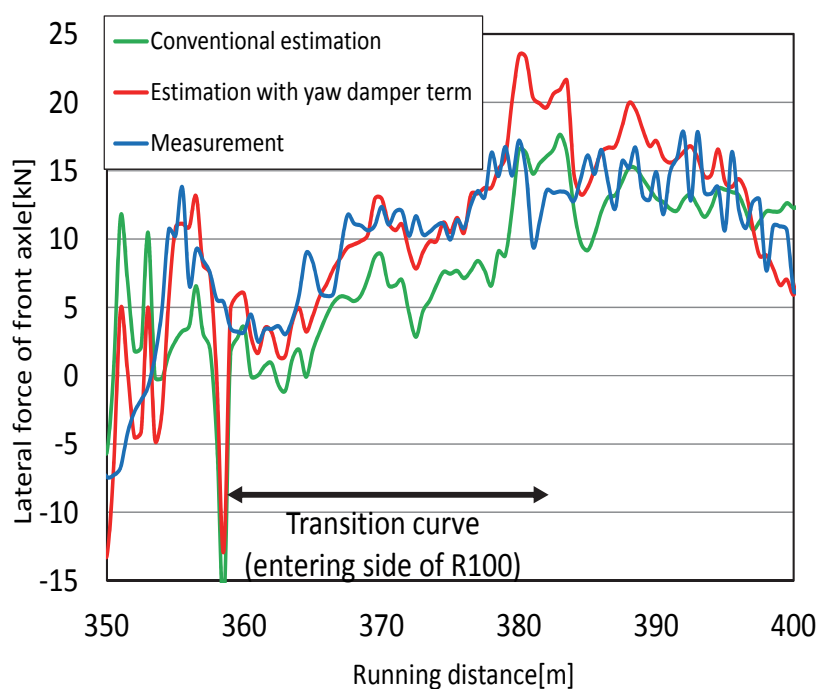

Fig. 13 Comparison between estimations of lateral force of front axle and measurement during transition curve passage

\section{$3 \cdot 3$ 台車旋回モーメントに着目した横圧推定式の提案}

3 ・2 節で述べたように, 台車旋回モーメントを発生要素毎に精査し, 各発生要素が台車旋回モーメントに与 える影響とそれによる第 1 軸輪軸横圧変動分を定式化した。これらを整理すると，第 1 軸の輪軸横圧変動分 $\triangle \mathrm{Q}_{\mathrm{AS}}^{\prime}$ は式（19）のように表わされる.

$$
\Delta \mathrm{Q}_{\mathrm{AS}}^{\prime}=\Delta \mathrm{Q}_{\mathrm{TF}}+\Delta \mathrm{Q}_{\mathrm{A} 2}+\Delta Q_{\widetilde{A S}}+\Delta Q_{Y D}
$$

また，軌道狂い・継目衝撃による横圧変動分についても別途精查を行い，軌道検測データとカント不足量の変動 成分 $\boldsymbol{\Delta} \mathbf{Q}_{\mathbf{C d}}$ から横圧の変動分を推定する手法を導入した（西本，山口，2014）。これより，軌道狂い・継目衝撃に よる横圧変動分 $\Delta \mathbf{Q}_{\mathrm{AD}}{ }^{\prime}+\Delta \mathbf{Q}_{\mathrm{unsp}}^{\prime}$ を式（20）のように表わす.

$$
\Delta \mathrm{Q}_{\mathrm{AD}}{ }^{\prime}+\Delta \mathrm{Q}_{\mathrm{unsp}}^{\prime}=A \frac{L}{10} \Delta Q_{\mathrm{Cd}}+B
$$

ただし，Lは軌道検測弦長， $\boldsymbol{A}, \boldsymbol{B}$ は走行試験結果により同定した係数でそれぞれ $\boldsymbol{A}=11.7, \boldsymbol{B}=\mathbf{3 . 7}$ である.

以上より，新しい横圧推定手法として次式を提案する.

$$
\mathrm{Q}_{0}=\overline{\mathrm{Q}}_{1}+\Delta \mathrm{Q}_{\mathrm{AS}}{ }^{\prime}+\Delta \mathrm{Q}_{\mathrm{AD}}{ }^{\prime}+\Delta \mathrm{Q}_{\mathrm{unsp}}^{\prime}
$$




\section{$3 \cdot 4$ 第 1 軸輪軸横圧が輪重に及ぼす影響}

2.1 節で述べたように，急曲線部を第 1 軸の外軌側車輪がフランジ接触状態で走行している際には，フラン ジ・レール接触部に作用する法線力は輪軸横圧変化の影響を受ける。この時の力のつり合いを図 14 に示す。こ こで, 輪軸横圧の変化による輪重変化分を $\Delta P_{A Q}$ とし, 第 1 軸外軌側において, 横クリープ力が摩擦力 $\mu N_{1 o u t} に$ 飽和していると仮定すると, 次式の関係が成り立つ.

$$
\Delta P_{A Q}=\Delta N_{1 \text { out }} \cos \alpha+\mu \Delta N_{1 \text { out }} \sin \alpha
$$

\section{Outer wheel}

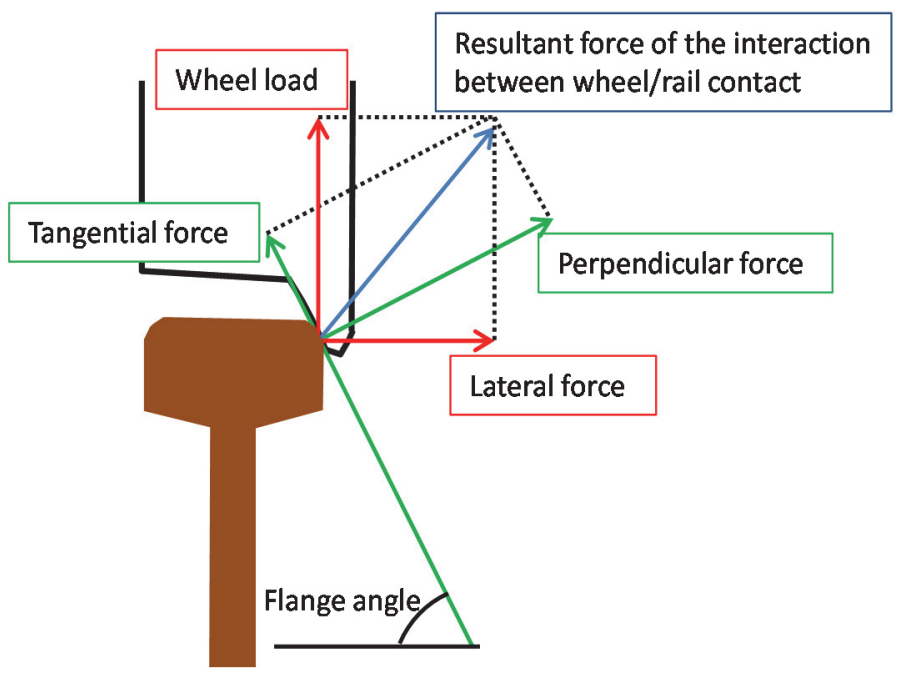

Fig. 14 Interaction between outer wheel and rail

また，図 14 に示す力のつり合いを考えると，輪軸横圧変化分 $\Delta \mathrm{Q}_{\mathrm{AS}}^{\prime}$ は式（23）で表わされる.

$$
\Delta \mathrm{Q}_{\mathrm{AS}}^{\prime}=\Delta N_{1 \text { out }} \sin \alpha-\mu \Delta N_{1 \text { out }} \cos \alpha
$$

式（22），(23）を $\Delta N_{1 \text { out }}$ について解くことにより，式（24）を導くことができる.

$$
\Delta P_{A Q}=\frac{\cos \alpha+\mu \sin \alpha}{\sin \alpha-\mu \cos \alpha} \Delta Q_{A S}^{\prime}
$$

式（24）に式（19）を代入すれば，輪軸横圧の変化による輪重変化分を $\Delta P_{A Q}$ を導くことができる．以上より， 第 1 軸の外軌輪重 $P_{o}$ と内軌輪重 $P_{i}$ は, $\Delta P_{A Q}$ を用いて式 $(25)$ のように書くことができる.

$$
\begin{aligned}
& P_{o}=\bar{P}_{o}-\overline{\Delta P}+\lambda \Delta P_{A Q} \\
& P_{i}=\bar{P}_{l}-\overline{\Delta P}-\lambda \Delta P_{A Q}
\end{aligned}
$$

ただし， $\lambda$ は第 1 軸外軌のフランジ接触状態を示す係数であり軌道の曲線半径や第 1 軸のアタック角により変化 する量である. 外軌側フランジ直線部がレールと接触している場合には $\lambda=1$ と与えられる. 本手法により, 輪 軸横圧による輪重変動を，より実態に即した值を用いて導くことができるようになる．本手法を用いた第 1 軸内 外軌輪重の算出結果は 4 章に示寸.

\section{4. 新しい横圧推定式による推定結果と実測値との比較}

前章で提案した新しい横圧推定式を検証するため, 急曲線部走行試験で得られた輪重と横圧の実測值と, 改良 推定式による推定值を比較した，走行試験に用いた車両の空車時の諸元を表 1 に示す. 
Table 1 Specification of railway vehicle used in the running tests

\begin{tabular}{|l|l|l|}
\hline Item & Specifications & Unit \\
\hline Height of center of gravity of the vehicle & 1.7 & $\mathrm{~m}$ \\
\hline Static axle weight (No.1 axle) & 65 (RTRI test line) & $\mathrm{kN}$ \\
\hline Distance between axles & 53 (JRE test line) & $\mathrm{m}$ \\
\hline Distance between center of bogies & 2.1 & $\mathrm{~m}$ \\
\hline Lateral distance between secondary suspensions & 13.8 & $\mathrm{~mm}$ \\
\hline Vertical spring constant of axle spring/1 axle box & 1750 & $\mathrm{MN} / \mathrm{m}$ \\
\hline Vertical spring constant of secondary suspension/1 suspension device & 1.25 & $\mathrm{MN} / \mathrm{m}$ \\
\hline Wheel profile & 0.30 & \\
\hline Traction device & Modified arc profile & \\
\hline Type of axle box suspension & Single link & \\
\hline
\end{tabular}

RTRI 試験線を走行した際の輪重・横圧について, 改良推定式（式（21）, 式（25））による推定值と，実測值を 比較した例を図 15 に示寸. 本例では, 空車状態で, $\mathrm{PQ}$ 測定軸の左右車輪の静止輪重アンバランス $22 \%$ 条件で の走行試験結果を用いて比較検討を行った．走行安全性評価に重要な，外軌輪重・横圧の推定值については， $3 \cdot 2 \cdot 2$ 節で述べたように, 第 2 軸のアタック角が式(10)により算出される值を中心に, $\pm 0.02 \mathrm{deg}$ の範囲でばら つくものとして外軌輪重・横圧を推定し, その最大值と最小值との間の值を推定領域として表現した. 図 15 か

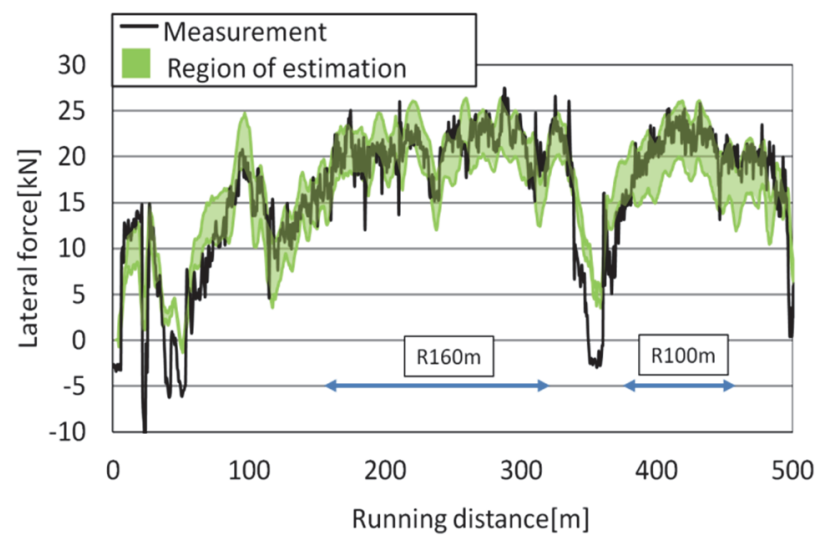

(a) Lateral force of outer wheel

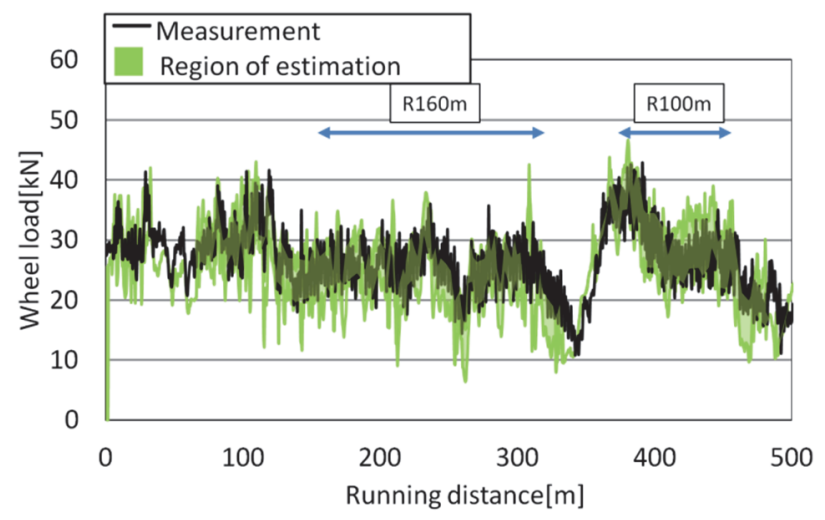

(c) Wheel load of outer wheel

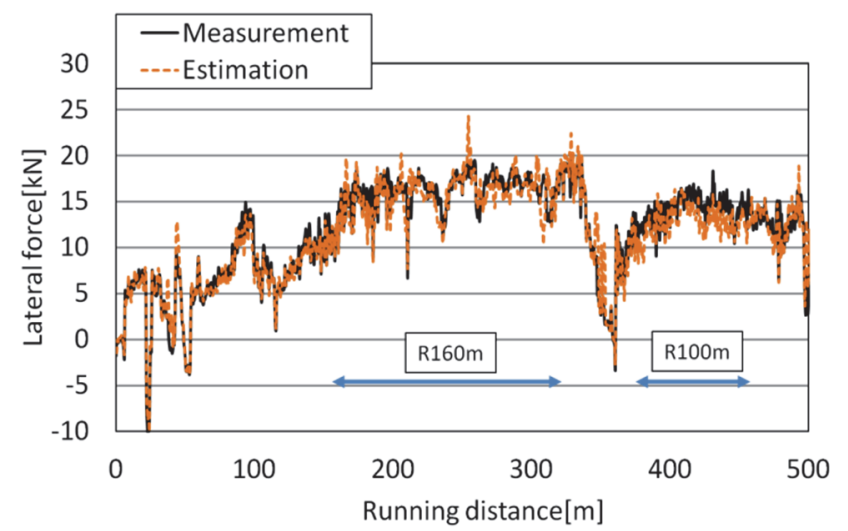

(b) Lateral force of inner wheel

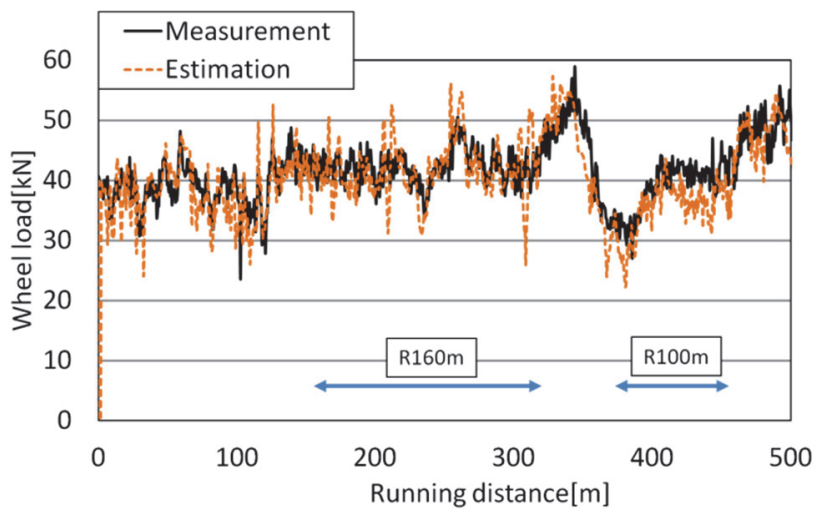

(d) Wheel load of inner wheel

Fig. 15 Comparison between estimated lateral force and wheel load of the front axle using proposed method and measurement of running test $(10 \mathrm{~km} / \mathrm{h}$, cant:90mm at R160m and R100m, RTRI test line) 
ら改良推定式により RTRI 試験線における走行試験の条件下において，実測值を精度よく再現できることが確認 できた。 ただし, 図 15 では, 特に外軌横圧について, 直線区間にあたる走行距離 $350 \mathrm{~m}$ 付近で実測值と推定値 が乘離している部分がある.この乘離は，今回提案した新しい横圧推定式は急曲線通過時の輪重・横圧推定を行 う目的に特化したものであり, 第 1 軸がフランジ接触状態で走行していることを前提条件としているために生じ たものである．直線区間周辺では外軌車輪フランジはレールに接触せずに走行する．第 1 軸外軌側車輪フランジ が接触しない状態では推定值が実測值よりも大きくなることは自明であるが，推定值が実際の值より大きくなる ことは安全性の判断のためには障害にはならないものと考える.

次に, JRE 試験線の半径 $100 \mathrm{~m}$ でカントが無い曲線部を $10 \mathrm{~km} / \mathrm{h}$ で走行した際の試験結果（飯島他，2013）を 用いて，第 1 軸内外軌の輪重・横圧について，先ほどと同様に実測值と推定值を比較した例を図 16 に示寸．本 例では，空車状態で，PQ 測定軸の左右車輪の静止輪重アンバランス $2 \%$ 条件での走行試験結果を用いて比較検 討を行った. 図 16 より, カント不足状態での走行条件においても, 改良推定式による曲線通過時の推定輪重・ 横圧が実測值を精度よく再現できることが確認できる.

改良推定式に入力する軌道変位データは，輪重・横圧変動に影響を及ぼす，本例では，軌道変位データから得 られる通り変位を, 軌道の曲率半径と第 1 軸アタック角の算出に用いた. 従来の軌道検測データは $5 \mathrm{~m}$ 弦あるい はそれ以上の弦長に処理されたデータで扱うことが一般的であるが，図 15,16 に示寸推定值の算出では $2 \mathrm{~m}$ 弦 の軌道検測データを用いており, 部分的に推定值が実測值から離れることがあるものの, 従来よりも短波長の, 軌道変位起因の輪重・横圧変動を考慮した推定值算出を実現している. 今後, さらに実測データを蓄積し, 改良 推定式の計算に用いる軌道検測データの適切な弦長を選択することにより, 推定結果の精度を向上できるものと 考えている.

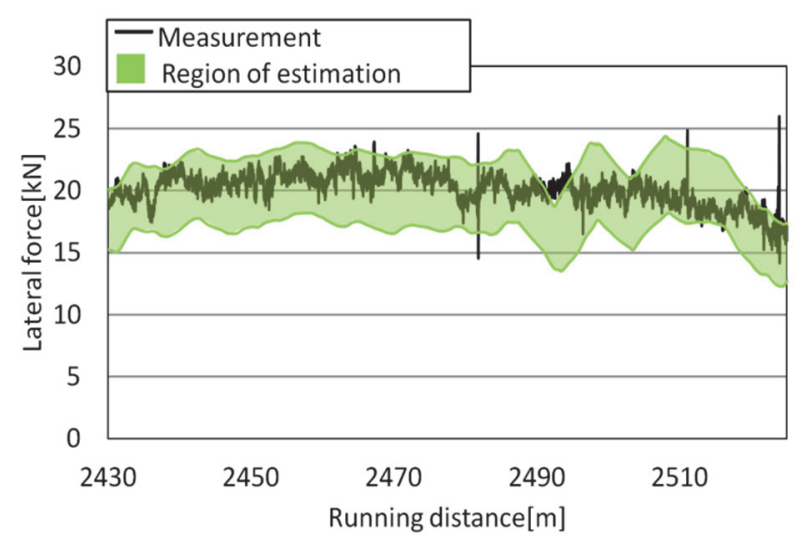

(a) Lateral force of outer wheel

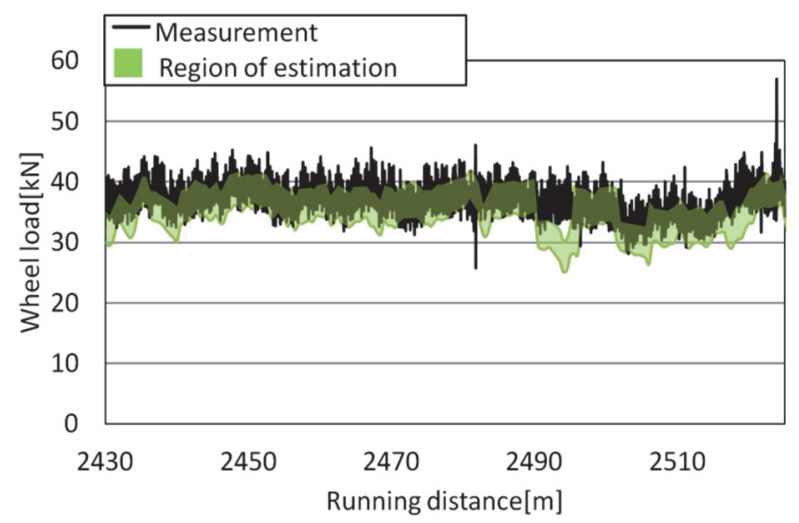

(c) Wheel load of outer wheel

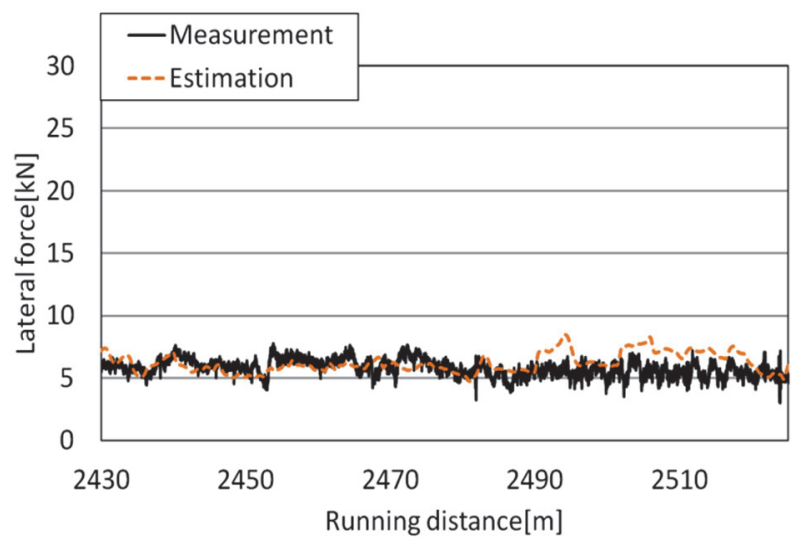

(b) Lateral force of inner wheel

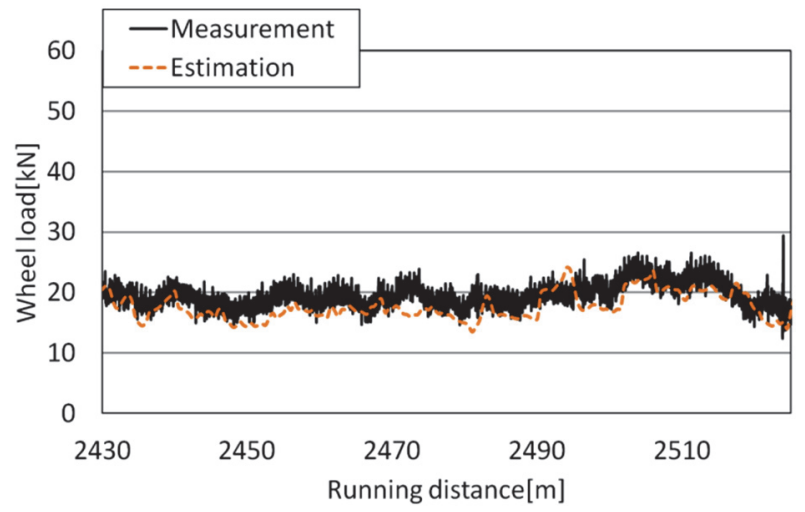

(d) Wheel load of inner wheel

Fig. 16 Comparison between estimated lateral force and wheel load of the front axle using proposed method and measurement of running test ( $10 \mathrm{~m} / \mathrm{h}$, cant:0mm, R100m, JRE test line) 


\section{5. まとめ}

従来より用いられている輪重横圧推定式の適用範囲を拡大寸ることを目的に，台車旋回モーメントに着目した 新しい輪重横圧推定式を提案した. 台車旋回モーメントの構成要素としては, 前後方向接線力, 第 2 軸の輪軸横 圧，枕ばね及びヨーダンパの剛性を考慮し，それぞれが台車旋回軸周りに与えるモーメントを，走行試験による 実測結果を基に精查, 定式化した. また, 第 1 軸の輪軸横圧変動が及ぼす輪重変化量についても合わせて検討し た. これらの検討をもとに, 急曲線のカント不足状態での走行にも適用可能な新しい輪重・横圧推定手法を提案 した. 本手法による輪重・横圧の推定結果を RTRI 試験線のようなカントの有る急曲線や JRE 試験線のようなカ ントが無い急曲線を走行した際の走行試験結果と比較した所，良く一致していることを確認した.

今後, 異なる線区を走行した際や車両条件, 走行条件が異なる場合のデータを蓄積し, 今回提案した横圧推定 式の精度向上をはかる予定である.

\section{文献}

飯島仁, 加藤幸夫, 日沖由理香, 田村大輔, 低速のり上がり脱線の根絶を目指して 第 7 報 脱線に深く関与寸 るアタック角と等価摩擦係数の関係, J-Rail2013 (2013), pp.617-620.

石田弘明，松尾雅樹，手塚和彦，植木健司，鉄道車両の新しい輪重，横圧，脱線係数連続測定法（測定装置の

開発)，日本機械学会論文集 C 編，Vol. 63，No. 614 (1997)， pp.3417-3423.

西本正人，山口剛志，列車荷重の変動成分の推定と脱線への影響に関する考察，J-Rail2014 (2014).

脱線に対する安全基準研究グループ，脱線に対する安全基準，鉄道技術研究報告車両編，No1306 (1968).

須田征男, 長門彰, 徳岡研三，三浦重，新しい線路 - 軌道の構造と管理 - , 社団法人日本鉄道施設協会 (1997).

国土交通省鉄道局監修・土木関係技術基準調查研究会編，鉄道に関寸る技術基準（土木編），社団法人鉄道施設 協会 (2002).

田中隆之, 土井久代, 中橋順一, 鈴木貢, 日比野有, 宮本岳史, 横圧推定式による台車旋回モーメントの走行試 験による検証, J-Rail2014 (2014).

田中隆之，飯田浩平，鈴木貢，飯田忠史，渡辺信行，西山幸夫，台車旋回性能試験装置の開発，鉄道総研報告， Vol. 27, No. 10 (2013), pp.23-28.

内田雅夫, 高井秀之, 村松浩成, 石田弘明, 輪重横圧推定式による乗り上がり脱線に対寸る安全性評価, 鉄道 総研報告, Vol. 15, No. 4 (2001), pp. 6-15.

\section{References}

Iijima, H., Kato, Y., Hioki, Y. and Tamura, D., A study to prevent the wheel-climb derailment on the low speed ranges The 7 nd report. A study on the attack angle of the wheel and equivalent coefficient of friction influenced on the wheel climb derailment. , J-Rail2013 (2013), pp.617-620 (in Japanese).

Ishida, H., Matsuo, M., Tezuka, K. and Ueki, K., Method of measuring wheel and rail contact forces and derailment quotients continuously(Development of measuring device), Transactions of Japan Society of Mechanical Engineers, Series C, Vol. 63, No. 614 (1997), pp.3417-3423 (in Japanese).

Nishimoto, M. and Yamaguchi, T., A method for estimating varying of rail contact forces causing flange climbing derailment, J-Rail2014 (2014) (in Japanese).

Safety Standards Research Group for Derailment, Safety standards for derailment, Railway Technical Research Report, No.1306 (1968) (in Japanese).

Suda, Y., Nagato, A., Tokuoka, K. and Miura, S., Atarashii-senro -kidou-no-kouzo-to-kanri-, Japan Railway Civil Engineering Association (1997).

Supervised by Ministry of Land Infrastructure, Transport and Tourism, Edited by Doboku-kankei-gijyutsu-chosa-kenkyukai, Tetsudo-ni-kansuru-gijyutsukijyun(Doboku-hen), Japan Railway Civil Engineering Association, Vol. 1(2002) and Vol. 2(2007) (in Japanese).

Tanaka, T., Doi, H., Nakahashi, J., Suzuki, M., Hibino, Y. and Miyamoto, T., Verification of bogie's rotational moment in theLateral-force estimation equation by the running tests, J-Rail2014 (2014) (in Japanese).

Tanaka, T., Iida, K., Suzuki, M., Iida, T., Watanabe, N. and Nishiyama, Y., Development of bogie rotational resistance test machine, RTRI report, Vol. 27, No. 10 (2013), pp.23-28 (in Japanese). 
Tanaka, Doi, Miyamoto and Iijima, Transactions of the JSME (in Japanese), Vol.82, No.842 (2016)

Uchida, M., Takai, H., Muramatsu, H. and Ishida, H., Evaluation of derailment safety using Lateral-force/Wheel-load estimation equations, RTRI Report, Vol. 15, No. 4 (2001), pp.6-15 (in Japanese). 